\title{
PASSIVATION OF DENTAL AMALGAMS AND MERCURY RELEASE
}

\author{
Luděk Joska ${ }^{1}$, Miroslav Marek ${ }^{2}$ \\ Institute of Chemical Technology, Prague, Czech Republic: Department of Metals and Corrosion Engineering ${ }^{1}$; Georgia \\ Institute of Technology, Atlanta, U. S. A.: GTRI/EOEML ${ }^{2}$
}

\begin{abstract}
Summary: Objectives: In this study the rate of dissolution of mercury from two dental amalgams with different compositions and structures was determined in vitro under different oxidation and abrasion conditions, and the results were correlated with the electrochemical characteristics. Methods: A spherical high copper and a lathe-cut very high-copper amalgam were tested in aerated and deaerated artificial saliva. The electrochemical characteristics were determined by potential-time, anodic polarization, polarization resistance and cathodic stripping measurements. Mercury release tests were performed after either stabilization in the solution, or abrasion using SiC papers or rotary toothbrush, with or without toothpaste. Dissolved mercury was determined by atomic absorption spectrophotometry. Results: Both amalgams exhibited passivation, the amalgam with the higher copper content passivating spontaneously even when the oxygen content in the solution was minimized. At a higher oxygen content in the solution the rate of mercury release from the amalgams was lower than when the oxygen content was minimized, and decreased further after a pre-exposure. Brushing generally increased the release. Significance: The results show the importance of the oxidation conditions and passivation characteristics of dental amalgams for mercury release, especially in the transient state after abrasion by chewing or tooth brushing.
\end{abstract}

Key words: Dental amalgam; Passivation; Abrasion

\section{Introduction}

The release of mercury from dental amalgam restorations remains a matter of public and scientific interest. Numerous studies have been reported regarding the mechanism and rate of mercury release in vivo and in vitro and using a variety of experimental techniques. Several critical reviews of the literature on mercury release in vivo have been published $(2,8,10,11,12,25,26)$.

There is evidence that the mercury release rate is primarily affected by the presence or absence of a tin oxide film on the $\gamma_{1}(\mathrm{Ag}-\mathrm{Hg}-\mathrm{Sn})$ phase, which is the matrix of the dental amalgam structure and is richest in mercury $(15,16$, 28). Correlations between the tin content in the $\gamma_{1}$ phase and mercury evaporation and dissolution have been reported $(6,7,13,14,15)$. Models of mercury release and of the tin oxide formation and its effect on mercury release have been proposed $(14,16)$.

If the tin oxide film serves as an effective barrier to the mercury release, its thinning or removal would result in an increase in the mercury release rate. Gum chewing, mastication or tooth brushing may cause such a degradation of the oxide film. Berglund (2) measured the intra-oral mercury vapor release and reported spikes corresponding to chewing and brushing. Mercury release has been reported to be significantly increased by chewing gum (3). An artifi- cial mouth has been used to study the effect of chewing and brushing on mercury release in vitro (1).

Since the oxide film barrier on the $\gamma_{1}$ phase forms electrochemically by reaction of the dissolved tin with the electrolyte, it reforms spontaneously following thinning or removal by mechanical abrasion. The amount of mercury released during a time period involving abrasion then depends on the kinetics of the film growth. This kinetics may be affected by chemical and electrochemical conditions, such as acidity and oxidation power of the electrolyte, as well as by the properties of the amalgam. In this study the mercury release was examined for two high-copper amalgams of different composition and structure and for several oxidation and abrasion conditions, and the results were correlated with the electrochemical behavior of the amalgams.

\section{Materials and methods}

Two commercial high-copper, single alloy composition amalgams were examined. The nominal compositions, provided by the manufacturers, and alloy/mercury ratios are presented in Table 1 (volume fractions of the $\gamma_{1}$ phase were determined by image analysis). Tytin is a typical spherical high-copper amalgam alloy with $60 \% \mathrm{Ag}$ and sufficient copper content (12\%) to eliminate the $\gamma_{2}$ phase. ANA 2000 is a low-silver (43\%), very high-copper $(\sim 25 \%)$ amalgam alloy, 
lathe-cut, containing some mercury (2\%) and used with a higher mercury/alloy ratio than Tytin. The amalgams were selected on the basis of an earlier study, which showed substantial difference in the electrochemical behavior (9).

The alloys were mixed according to manufacturers' instructions, and standard specimens $4 \mathrm{~mm}$ dia. were prepared according to ISO 1559. Samples for testing were prepared by attaching four specimens of the same amalgam to a brass stud using conductive glue, and casting the assembly in epoxy resin. The epoxy casting was machined to expose the cross-sections of the four specimens (exposed area $0,5 \mathrm{~cm}^{2}$ ) and to a conical shape serving as a plug for a weighing bottle with a standard ground glass taper. In addition to the amalgams, specimens of pure copper (purity 99,995 wt \%, VUK, Czech Republic) and Sn (purity 99,999 wt \%, VUK, Czech Republic) were prepared for the polarization tests.

All electrochemical and dissolution measurements were performed using artificial saliva of the following composition and conditions: $\mathrm{KCl}: 20,1 \mathrm{mmol} / 1 ; \mathrm{NaHCO}_{3}: 17,9 \mathrm{mmol} / \mathrm{l}$; $\mathrm{NaH}_{2} \mathrm{PO}_{4}: 3,6 \mathrm{mmol} / 1$; KSCN: $5,1 \mathrm{mmol} / 1$; lactic acid: 0,10 $\mathrm{mmol} / 1$, pH 6,8 , temperature $37 \pm 0.5^{\circ} \mathrm{C}$. The atmosphere was controlled by bubbling through the solution before the test a mixture of either $\mathrm{N}_{2} / 10 \% \mathrm{CO}_{2}$ for $2 \mathrm{~h}$ (deaerated, oxygen content minimized), or air $/ 10 \% \mathrm{CO}_{2}$ for $1 \mathrm{~h}$ (aerated, oxygen content similar to the conditions in the oral cavity).

The electrochemical tests were performed using a standard 3-electrode glass test cell with a jacket for temperature control by a flow of water from a constant-temperature circulator. The electrochemical system was a model PC4/Fas (Gamry, U.S.A). The tests consisted of potential-time, anodic polarization, polarization resistance and galvanostatic measurements. The open-circuit potentials were measured in both aerated and deaerated electrolytes after wet-grinding the specimens on FEPA P2400 SiC papers. The potentials were measured with respect to a $\mathrm{Ag} / \mathrm{AgCl} / 3 \mathrm{~mol} / \mathrm{L} \mathrm{KCl}$ reference electrode, and the values were converted to the Standard Hydrogen Electrode (SHE) scale. Before the exposure in the deaerated electrolyte the surface oxides were stripped by cathodic reduction for $60 \mathrm{~s}$ at $-0.82 \mathrm{~V} / \mathrm{SHE}$. The potentials were recorded for $2 \mathrm{~h}$. For the potentiodynamic polarization measurements the electrolyte was deaerated, the specimens were wet-ground on FEPA P2400 SiC papers, and the surface oxides were stripped before the scan initiation by cathodic reduction for $60 \mathrm{~s}$ at $-0.82 \mathrm{~V} / \mathrm{SHE}$. The polarization curves were recorded at a potential scanning rate of $1 \mathrm{mV} / \mathrm{s}$ from a potential $0.1 \mathrm{~V}$ below the open circuit potential to $0.4 \mathrm{~V} / \mathrm{SHE}$. The polarization resistance $\mathrm{R}_{\mathrm{p}}$ was measured as a function of time for ANA 2000 in aerated and deaerated solutions by scanning the potential at a rate of $0.5 \mathrm{mV} / \mathrm{s}$ in the range of $\pm 15 \mathrm{mV}$ from the open circuit potential and determining $\mathrm{R}_{\mathrm{p}}$ as the slope of the potential vs. current density line at the open-circuit potential.

A qualitative determination of the presence or absence of a reducible oxide was obtained by galvanostatic reduction in a deaerated electrolyte at $-0.4 \mathrm{~A} / \mathrm{m}^{2}$ for Tytin and $-0.9 \mathrm{~A} / \mathrm{m}^{2}$ for ANA 2000 . The presence of a plateau on the potential-time curve at about $-0.6 \mathrm{~V} / \mathrm{SHE}$ was taken as evidence of the presence of tin oxide on the surface. Specimens were tested after a 2 -h exposure to either aerated or deaerated synthetic saliva at $37^{\circ} \mathrm{C}$.

The mercury dissolution tests were performed using standard $12 \mathrm{ml}$ glass weighing bottles with a ground-glass neck, into which the specimens could be inserted. The bottles were filled with aerated or deaerated artificial saliva, which was pre-warmed to $37^{\circ} \mathrm{C}$. After specimen insertion the bottles were placed in an incubator and maintained at $37^{\circ} \mathrm{C}$ for $2 \mathrm{~h}$. The solution from each bottle was then stabilized by addition of $10 \mathrm{ml}$ of a solution of $1 \mathrm{~g} / 1$ of $\mathrm{K}_{2} \mathrm{Cr}_{2} \mathrm{O}_{7}$ in $30 \%$ $\mathrm{HNO}_{3}$, and analyzed for mercury using an atomic absorption spectrophotometer with a cold-vapor generation accessory (Models SpectrAA-300 and VGA-76, respectively, Varian Techtron Pty, Australia). The detection limit was 0.1 ppb. Four to eight analyses were performed for each solution sample, as well as for appropriate standards. The results of four replicate tests were averaged to obtain the mean values and standard deviations; the means were compared using student's t-test at $\mathrm{p}=0,05$.

Before the mercury dissolution exposures the surfaces of the specimens were prepared using one of the following procedures:

a. Wet-grinding using FEPA P2400 SiC paper.

b. Wet-grinding using FEPA P2400 SiC paper and an opencircuit pre-exposure in the aerated electrolyte for $2 \mathrm{~h}$.

c. Brushing without toothpaste using a rotary toothbrush (Sunbeam Model 4209, Sunbeam-Oster Household Products, U.S.A.) at a frequency of $2750 \mathrm{~min}^{-1}$, for $20 \mathrm{~s}$ in the aerated electrolyte at $37^{\circ} \mathrm{C}$.

d. Brushing with toothpaste in air using the same rotary toothbrush for $20 \mathrm{~s}$, followed by rinsing with aerated electrolyte at $37^{\circ} \mathrm{C}$. A common commercial toothpaste, Colgate Cavity Protection (Colgate-Palmolive Co., U.S.A.), $\mathrm{pH}=7,3, \mathrm{E}_{\text {redox }}=0,300 \mathrm{~V} / \mathrm{SHE}$, was used in this procedure.

\section{Results}

The results of the open circuit potential measurements for the two amalgams in both aerated and deaerated electro-

Tab. 1: Materials tested.

\begin{tabular}{|l|c|c|c|c|c|c|c|}
\hline Amalgam & $\begin{array}{c}\mathrm{Ag} \\
\text { [wt.\%] }\end{array}$ & $\begin{array}{c}\mathrm{Cu} \\
{[\text { wt.\%] }}\end{array}$ & $\begin{array}{c}\mathrm{Sn} \\
\text { [wt.\%] }\end{array}$ & $\begin{array}{c}\text { Hg in alloy } \\
\text { [wt.\%] }\end{array}$ & $\begin{array}{c}\text { Alloy to Hg } \\
\text { ratio }\end{array}$ & $\begin{array}{c}\gamma^{1} \text { volume } \\
\text { fraction }\end{array}$ & Manufacturer \\
\hline ANA 2000 & 43.0 & 25.4 & 29.6 & 2.0 & $1: 1$ & $0,54(\mathrm{SD}=0,05)$ & Nordiska Dental AB, Sweden \\
\hline Tytin & 60.0 & 12.0 & 28.0 & - & $1: 0,74$ & $0,36(\mathrm{SD}=0,07)$ & Kerr, U.S.A. \\
\hline
\end{tabular}


lytes as a function of the exposure time are presented in Fig. 1. The potential of ANA 2000 increased with time for both conditions and stabilized at a potential about $100 \mathrm{mV}$ higher in the solution saturated with a gas mixture containing $10 \%$ oxygen (aerated) than in the solution, in which dissolved oxygen was minimized (deaerated). The potential of Tytin showed an initial fast increase and stabilization in the deaerated solution at a potential about $400 \mathrm{mV}$ more negative than ANA 2000 under the same conditions. In the

Tab. 2: Evidence of tin oxide after 2-h exposure.

\begin{tabular}{|l|c|c|}
\hline & Deaerated electrolyte & Aerated electrolyte \\
\hline Tytin & no & yes \\
\hline ANA 2000 & yes & yes \\
\hline
\end{tabular}

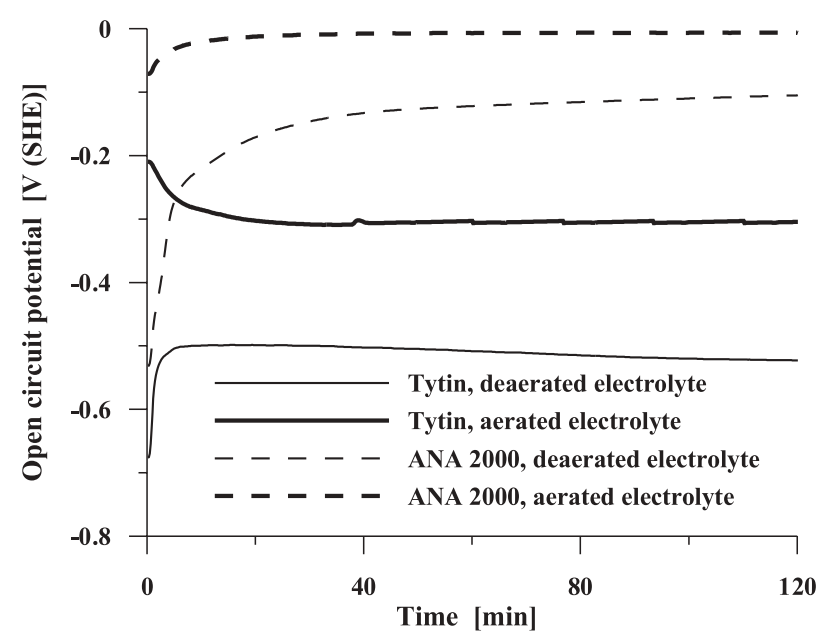

Fig. 1: Open circuit potentials of Tytin and ANA 2000 amalgams as a function of exposure time in aerated and deaerated artificial saliva at $37^{\circ} \mathrm{C}$.

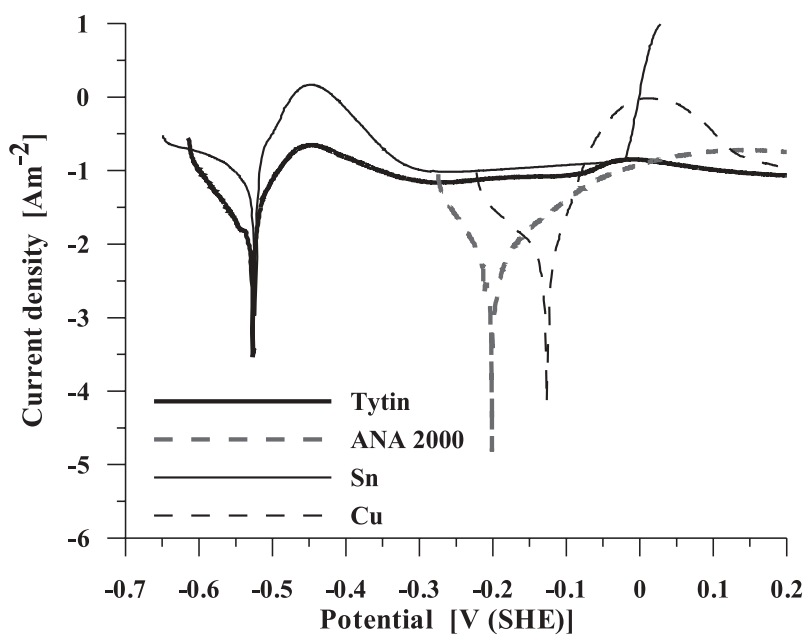

Fig. 2: Polarization curves for Tytin and ANA 2000 amalgams, $\mathrm{Sn}$ and $\mathrm{Cu}$ in deaerated artificial saliva at $37^{\circ} \mathrm{C}$. aerated solution the potential initially decreased and stabilized a value about $200 \mathrm{mV}$ higher than in the deaerated solution, but about $300 \mathrm{mV}$ more negative than the potential of ANA 2000 under the same conditions.

The polarization curves for both amalgams, as well as those for pure tin and copper in the deaerated solution are presented in Fig. 2. The curves for both Tytin and Sn showed a primary passivation peak at about $-0,45 \mathrm{~V} / \mathrm{SHE}$, while the curve for ANA 2000 exhibited only passive behavior in

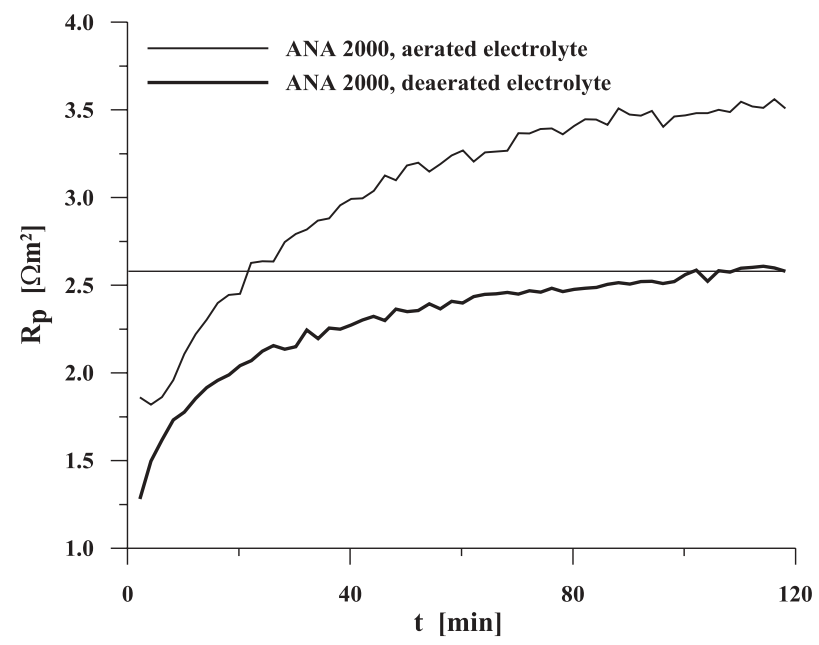

Fig. 3: Polarization resistance of ANA 2000 amalgam as a function of exposure time in aerated and deaerated artificial saliva at $37^{\circ} \mathrm{C}$.

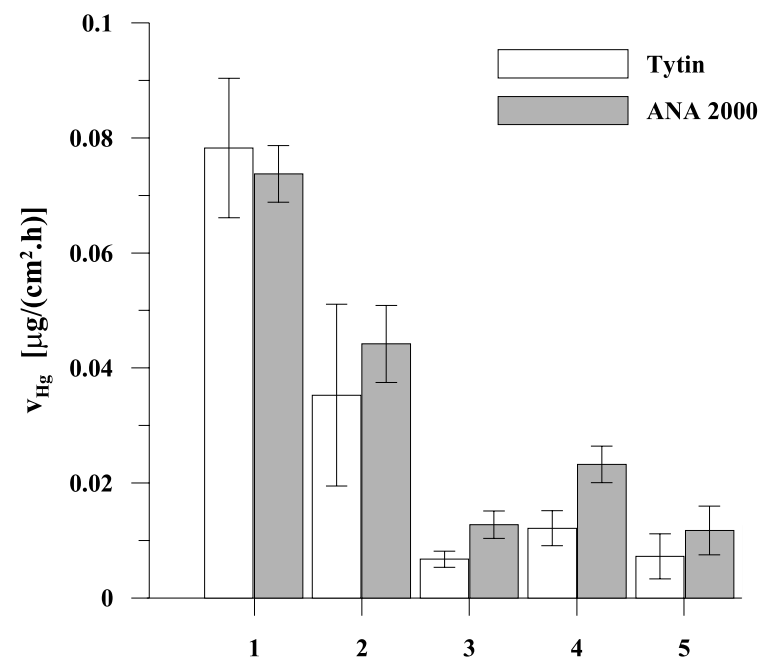

Fig. 4: Average dissolution rates for 2-h exposures of Tytin and ANA 2000 amalgams in artificial saliva at $37^{\circ} \mathrm{C}$. (1) Wet-ground, deaerated electrolyte. (2) Wet-ground, aerated electrolyte. (3) 2-h pre-exposure in aerated electrolyte. (4) Brushed with a rotary toothbrush without toothpaste, aerated electrolyte. (5) Brushed with Colgate toothpaste, aerated electrolyte. Bars show means of at least 4 replicate tests; error bars show \pm standard deviation. 
the range of potentials examined. The polarization results for copper showed a broad peak at about $0 \mathrm{~V} / \mathrm{SHE}$, at which potential a small peak on the curve for Tytin also was observed. A sharp increase in current, indicating breakdown of passivity was observed for tin at about $0 \mathrm{~V} / \mathrm{SHE}$, but not for either of the amalgams.

Results of the galvanostatic tests are summarized in Table 2. Evidence of the presence of a surface oxide was found for ANA 2000 under both oxygenated and deoxygenated conditions, for Tytin only in the oxygenated solution. The polarization resistance $R_{p}$, which is inversely proportional to the rate of electrochemical reaction, as a function of the exposure time in aerated and deaerated solutions for ANA 2000 is presented in Fig. 3.

The results of the mercury release measurements are summarized in Fig. 4. For exposure in the deaerated electrolyte immediately following wet-grinding there was no significant difference between the amalgams in the 2-h release rate. In the presence of oxygen (aerated solution) the means were significantly lower than in the deaerated solution $(\mathrm{p}=0,05)$.

When the release rate was measured in the aerated solution after a $2 \mathrm{~h}$ pre-exposure, the means were significantly lower than during the first two hours, and lower for Tytin than for ANA $2000(p=0,05)$. Brushing without toothpaste increased the mercury release rate, and the rate was significantly higher for ANA 2000 than for Tytin $(p=0,05)$ Brushing with toothpaste, however, did not significantly affect the mercury release rate.

\section{Discussion and conclusions}

The release of mercury from dental amalgam and the electrochemical behavior of the amalgam are related because electrochemical reactions in the oral environment change the state of the surface, through which mercury evaporates or dissolves. The two amalgams examined in this study exhibited substantially different electrochemical potentials in synthetic saliva, as shown in Fig. 1. The open circuit potential of the amalgam is a mixed potential, affected by the anodic and cathodic reactions on all the exposed phases of the microstructure. The open circuit potential of Tytin in deaerated electrolyte, after reduction of the surface oxide has stabilized at $\mathrm{E}=-0,51 \mathrm{~V} / \mathrm{SHE}$. This value is close to the equilibrium potential of the $\mathrm{Sn}(\mathrm{OH})_{2} / \mathrm{Sn}$ couple $(\mathrm{E}=$ $-0,492 \mathrm{~V} / \mathrm{SHE}$ at the $\mathrm{pH}$ and temperature of the electrolyte) (4). Since a shift in the potential in the positive direction would require oxidation of the tin in the tin-containing phases, the open circuit potential in a solution of low oxidation power remained close to the equilibrium potential.

In a solution containing air the potential of Tytin was more positive by about $0,2 \mathrm{~V}$ than in the deaerated electrolyte, and was in the passive region (see Fig. 2) due to the increased oxidizing power of the electrolyte resulting in increased cathodic reaction rate. The open circuit potential of the amalgam remained well below the potential for dis- solution of copper (standard equilibrium potential for $\mathrm{Cu}^{2+} / \mathrm{Cu} \mathrm{E}^{\mathrm{o}}=0,340 \mathrm{~V}$ ) or the potential for oxidation of copper to cuprous oxide $\mathrm{Cu}_{2} \mathrm{O}(\mathrm{E}=0,053 \mathrm{~V}$ (SHE) at the $\mathrm{pH}$ and temperature of the electrolyte) (5).

The stabilized open circuit potential of ANA 2000 was more positive by about 0,3 to $0,5 \mathrm{~V}$ than the potential of Tytin and was in the region of passivity in both the aerated and deaerated electrolytes (Figs. 1 and 2). This means that ANA 2000 passivates spontaneously even in the absence of oxygen in the electrolyte by electrochemical reaction with water resulting in oxidation of tin. The difference between the open circuit potentials of the two amalgams can be attributed to the substantially higher copper content in ANA 2000. The potential is near to the theoretical potential of the $\mathrm{Cu} / \mathrm{Cu}_{2} \mathrm{O}$ equilibrium, oxidation of copper may be expected because of the destabilizing effect of mercury on the oxide films on $\eta^{\prime}$ (24).

The qualitative results of the galvanostatic stripping tests for the presence or absence of tin oxide following different exposure conditions, presented in Table 2, were consistent with the interpretation of the potential and polarization data. No oxide was detected on Tytin after a 2-h exposure in deaerated electrolyte, provided that the initial, air-formed oxide was cathodically stripped. Under the same exposure conditions, however, oxide was found on ANA 2000. Oxide was found on both amalgams after exposure to the aerated electrolyte, in agreement with the potential and polarization data showing that both amalgams in the presence of dissolved oxygen passivated spontaneously.

The results presented in Fig. 4 show that there was no statistically significant difference $(p \leq 0,05)$ between the two amalgams in the mercury release when they were tested after wet-grinding in either aerated or deaerated electrolyte. In the aerated electrolyte the average release was significantly lower than in the absence of dissolved oxygen for both amalgams, confirming that an oxide barrier to the mercury release was formed on the $\gamma_{1}$ phase in the solution of higher oxidation power.

The key difference between the two amalgams in the mercury release was shown by the results for an aerated electrolyte after a 2-hour pre-exposure. According to the electrochemical results both amalgams were in a passive state under this condition, but significantly more mercury was dissolved from ANA 2000 than from Tytin. The rate of mercury release is primarily affected by the area of the mercury-rich $\gamma_{1}$ phase and the tin content in this phase (15), because the tin oxide surface film that forms by oxidation of tin in the $\gamma_{1}$ phase is a barrier to the mercury release. Although the amount of tin in the $\gamma_{1}$ phase of ANA 2000 was not found in the literature, it is likely to be similar to the amount in Tytin (1,25 wt.\%), based on the data for similar alloys (15). The higher rate of mercury release from ANA 2000 thus can be attributed mainly to a higher volume and surface area ratio of the $\gamma_{1}$ phase.

When the oxygen content in the solution was minimized, the oxide barrier on the $\gamma_{1}$ phase in Tytin was mini- 
mal while ANA 2000 still passivated spontaneously, and there was not significant difference in the mercury release rate between the two amalgams. Since the mercury release was measured during a 2-h exposure immediately following wet-grinding and cathodic stripping of the oxide, the result is an average for a period, in which substantial changes in the surface condition occur by formation or growth of an oxide film barrier on the $\gamma_{1}$ phase. The increase in the polarization resistance with time, presented in Fig. 3 for ANA 2000 , shows that it takes more than two hours for the amalgam to reach a relatively stabilized surface condition and that the kinetics of passivation depends on oxygen concentration in electrolyte. This may explain why the release rate from ANA 2000 was not more dramatically lower than from Tytin, in spite of the larger source of mercury. For the aerated solution, there was again no statistically significant difference in mercury release during the first two hours of exposure, as both amalgams developed the oxide film barrier on the $\gamma_{1}$ phase, which reduced the mercury release. The mercury release rate dropped significantly more for Tytin than for ANA 2000 compared with the release under the condition of deaeration. This difference is consistent with the electrochemical evidence that aeration caused a change for Tytin from incipient passivation to a fully passive state, while ANA 2000 was passive under both conditions. The potential increase thus made a larger difference for Tytin, on which it allowed an effective oxide film to form, than for ANA, on which the oxide film only thickened.

Abrasion due to brushing is expected to thin the surface oxide on the $\gamma_{1}$ phase and thus increase the mercury release rate. Berglund (2) reported increased mercury emission as a result of toothbrushing under clinical conditions. The simulated in vitro brushing used in this study after a 2 -h preexposure in aerated electrolyte increased mercury dissolution for brushing without a tooth paste but not for brushing with tooth paste, possibly due to a lubricating effect of the toothpaste or formation of corrosion products by reaction with the components of the toothpaste. The increase was, however, relatively small compared with the complete removal of the surface oxide by wet-grinding on a $\mathrm{SiC}$ paper.

The results of this study show that the oxidation conditions in the environment and passivation characteristics of the amalgam both play an important role in the mercury release, especially under transient conditions, such as after an abrasion event. While the tin content and volume fraction of the $\gamma_{1}$ phase have primary effects on the formation of the oxide diffusion barrier, other phases of the microstructure affect the passivation process by their effect on the actual electrochemical potential and kinetics of the reactions. The mercury release is further affected by the presence of other substances during and after abrasion by chewing or toothbrushing through variation in the oxidation power, chemistry and abrasiveness of the environment.

The article deals with the effect of the interaction of dental amalgam with a simulated oral environment on mer- cury release, presenting one of the possible views of the subject. An extensive and exhaustive collection of review articles assessing various aspects of the use of dental amalgams has been published by Novak et al. (17-23,27).

In high-copper amalgams, mercury is released practically solely from phase $\gamma_{1}$. The „wetter“ amalgam is prepared, i.e. the more mercury is used for amalgamation, the larger mercury source area is created. From this, and not only this, point of view it is clearly desirable to use amalgams dosed by the manufacturer and amalgams with a mercury content below 50 percent by weight. A broad range of materials of different composition are available at present. From the practical point of view we may state that the choice of a high-copper amalgam from among materials with a higher tin content provides for a higher level of phase $\gamma_{1}$ alloying with this element, and consequently for a lower extent of the patient's burdening with mercury. As shown by this study on amalgams with largely different electrochemical properties, the kinetics of the formation of a layer based on tin oxide affects the rate of mercury release. However, the differences found during the study were never extreme.

\section{Acknowledgements}

This investigation was supported by research project MSM 223100002 from the Ministry of Education, Youth and Sports (Czech Republic).

\section{References}

1. Berdouses E, Vaidyanathan TK, Dastane A, Weisel C, Houpt M, Shey Z. Mercury release from dental amalgams: an in vitro study under controlled chewing and brushing in an artificial mouth. J Dent Res 1995;74:1185-93.

2. Berglund A. Estimation by a 24-hour study of the daily dose of intra-oral mercury vapor inhaled after release from dental amalgam. J Dent Res 1990;69:1646-51.

3. Bjorkman L, Lind B. Factors influencing mercury evaporation rate from denta amalgam fillings. Scand J Dent Res 1992;100:354-60.

4. Deltombe E, De Zoubov N, Vanleugenhaghe C, Pourbaix M. Tin. In: Pourbaix M, ed. Atlas of Electrochemical Equilibria in Aqueous Solutions, Houston: NACE, 1974:475-84

5. De Zoubov N, Vanleugenhaghe C, Pourbaix M. Copper. In: Pourbaix M, ed. Atlas of Electrochemical Equilibria in Aqueous Solutions, Houston: NACE, 1974: $384-92$

6. Feracane JL, Adey JD, Nakajima H, Okabe T. Mercury vaporization from amalgams with varied alloy compositions. J Dent Res 1995;74:1414-7.

7. Ferracane JL, Hanawa T, Okabe T. Effectiveness of oxide films in reducing mercury release from amalgam. J Dent Res 1992;71:1151-5.

8. Chen KI, Ju CP, Lin JH. Effect of particle configuration on structure and properties of dispersed Pd-containing dental amalgam. Biomaterials 1999;20: 1851-66.

9. Joska L, Bystrianský J, Novák P. The effect of the alloy powder preparation on the corrosion behaviour of dental amalgams, In: Proceedings of the $13^{\text {th }}$ ICC, Granada, Spain 2002

10. Krone CA, Ely JTA, Thoresen J. Method for measuring mercury release from dental amalgam. Bull Environ Contam Toxicol 2002;68:180-6.

11. Mackert JR, Berglund A. Mercury exposure from dental amalgam fillings: absorbed dose and the potential for adverse health effects. Crit Rev Oral Biol Med 1997;8:410-36

12. Mackert JR. Factors affecting estimation of dental mercury exposure from measurements of mercury vapor levels in intra-oral and expired air. J Dent Res 1987:66:1775-80.

13. Mahler DB, Adey JD, Fleming MA. Hg emission from dental amalgam as related to the amount of Sn in the Ag-Hg $\left(\gamma_{1}\right)$ phase. J Dent Res 1994;73: 1663-8.

14. Marek M. The effect of tin in the Ag-Hg phase of dental amalgam on dissolution of mercury. Dent Mat 1997;13:353-9.

15. Marek M. The effect of tin on the corrosion behavior of the Ag-Hg phase of dental amalgam and dissolution of mercury. J Dent Res 1990;69:1786-90. 
16. Marek M. The release of mercury from dental amalgam: The mechanism and in vitro testing. J Dent Res 1990;69:1167-74.

17. Novák L, Půža V, Červinka M, Kolářová J. Problematika amalgámových výplní. I. Historie a současnost amalgámu. Čes stomatol 1996;96:80-4.

18. Novák L, Půža V, Červinka M, Kolářová J. Problematika amalgámových výplni. II. Druhá amalgámová válka. Ces stomatol 1996:96:115-9.

19. Novák L, Půža V, Červinka M, Kolářová J. Problematika amalgámových výpln III. Rtư a její sloučeniny v životním prostředi. Čes stomatol 1996;96:156-61.

20. Novák L, Pủža V, Červinka M, Kolářová J. Problematika amalgámových výpln IV. Uvolňování par rtuti z amalgámových výplní. Čes stomatol 1996;96:196-203.

21. Novák L, Půža V, Červinka M, Kolářová J. Problematika amalgámových výplní. V. Zatížení ošetřujících a pacientů rtutí. Čes stomatol 1997;97:7-15.

22. Novák L, Půža V, Červinka M, Kolářová J. Problematika amalgámových výplni. VI. Amalgámová výplñ jako př́icina závažných onemocnění. Čes stomatol 1997;97:61-5.

23. Novák L, Půža V, Červinka M, Kolářová J. Probleomatika amalgámových výplni. VIII. Alternativní výplňové materiály za amalgám a závěr souboru prací zabývajících se problematikou amalgámových výplní. Čes stomatol 1997;97:157-62.

24. Ogletree RH, Marek M. Effect of mercury on corrosion of $\eta$ ' Cu-Sn phase in dental amalgams. Dent Mat 1995;11:332-6.

25. Okabe T, Elevbak B, Carrasco L, Ferracane JL. Mercury release from dental amalgams into continuously replenished liquids. Dent Mat 2003;19:38-45.
26. Olsson S, Bergman M. Daily dose calculations from measurements of intra-oral mercury vapor. J Dent Res 1992;71:414-23.

27. Půža V, Červinka M, Novák L, Chmelařová V, Kolářová J. Problematika amalgámových výplní. VII. Experimentální sledování cytotoxicity amalgámủ a jejich výluhů. Čes stomatol 1997;97:112-25.

28. Uo M, Berglund A, Cardenas J, Pohl L. Surface analysis of dental amalgams by X-ray photoelectron spectroscopy and X-ray diffraction. Dent Mat 2003;19: $639-44$

Submitted June 2004.

Accepted October 2004

Ing. Luděk Joska, CSc.,

Institute of Chemical Technology,

Department of Metals and Corrosion Engineering,

Technická 5, 16628 Praha 6, Czech Republic. e-mail: Ludek.Joska@vscht.cz 